\title{
Modeling in Petri Nets of a Dispersed System in a Physical Rehab
}

\author{
I. Ruiz' , J. I. Garcia², C. Collazos ${ }^{3}$ \\ ${ }^{1}$ Grupo de Investigación Aplicabilidad Tecnológica, Universidad Manuela Beltran, Bogotá, Colombia. \\ ${ }^{2}$ Grupo de Investigación en Mejoramiento Industrial, Universidad del Valle, Cali, Colombia \\ ${ }^{3}$ Grupo de Investigación Cincias Básicas y Laboratorios, Universidad Manuela Beltran, \\ Bogotá, Colombia.
}

\begin{abstract}
Considering the lack of resources in health centers located in rural zones, a part of Colombian population goes affected by the quality of the health Service received. If this is added the low level socioeconomic of some rural population, it is generated a geographic vulnerability. For that reason in this work is presented a Service Oriented Architecture that has as objective support health centers with low technical resources with technology that allows a physical rehab attention independently of the localization of patient and health professional. By way of this, a distributed system it is proposed, using a dispersed communication media like the internet. It is planned to make a modeling process based on a formal tool like the Petri Nets to assure the definition of the services, assistant dispositive teleoperation and the integration and coordination of the system.
\end{abstract}

Keywords - Modeling, Petri Nets, Rehab

\section{Modelado en Redes Petri de un sistema disPerso EN UNA REHABILITACIÓN FÍSICA}

\footnotetext{
Resumen-Considerando la falta de recursos en centros de salud ubicados en zonas rurales, una parte de la población colombiana se ve afectada por la calidad del Servicio de Salud recibido. Si se suma el bajo nivel socioeconómico de cierta población rural, se genera una vulnerabilidad geográfica. Por ello en este trabajo se presenta una Arquitectura Orientada a Servicios que tiene como objetivo apoyar centros de salud con bajos recursos técnicos con tecnología que permita una atención física de rehabilitación independientemente de la ubicación del paciente y profesional de la salud. De esta manera, se propone un sistema distribuido, utilizando un medio de comunicación disperso como Internet. Para asegurar la definición de los servicios, el asistente de teleoperación dispositiva y la integración y coordinación del sistema, se planea realizar un proceso de modelización basado en una herramienta formal como las redes de Petri.
}

Palabras clave-Modelado, Redes de Petri, Rehabilitación.

\% Dirección para correspondencia: ivan.ruiz@docentes.umb.edu.co

DOI: https://doi.org/10.24050/19099762.n21.2017.1172 


\section{Modelagem em Redes Petri de um sistema disPerso NUMA REABILITAÇÃO FÍSICA}

Resumo-Considerando a falta de recursos em centros de saúde localizados em zonas rurais, uma parte da população colombiana vê-se afetada pela qualidade do Serviço de Saúde recebido. Ao somar-se o baixo nível socioeconómico de alguma população rural, gera-se uma vulnerabilidade geográfica. Por isso neste trabalho apresenta-se uma arquitetura orientada a serviços que tem como objetivo apoiar centros de saúde com baixos recursos técnicos com tecnologia que permite uma atenção física de reabilitação independentemente da localização do paciente e profissional da saúde. Desta maneira, propõe-se um sistema distribuído, utilizando um médio de comunicação disperso como Internet. Para assegurar a definição dos serviços, o assistente de tele operação dispositiva e a integração e coordenação do sistema, planeja-se realizar um processo de modelização baseado numa ferramenta formal como as redes de Petri.

Palavras-chave-Modelagem, Redes de Petri, Reabilitação.

\section{INTRODUCTION}

$\mathrm{I}^{\mathrm{n}}$ Colombia, like other Latin-American countries, health system evidenced a critical situation in topics related to coverage, accessibility and quality [1]. That is added to the nonconformity of the society that judge in a hard way inefficiency, delays and Access barriers to the system and question permanently the quality, the attention agility and the technology costs [1].

In this way, a successful solution to this inconvenient is complex in function of the heterogeneity of the resources that could integrate the health system and the associated costs. Additionally, other aspects that contribute to increasing health problems is related to an inequitable distribution of the income, added to the frequent displacement for the violence makes than the infrastructure of the health Service presents serials difficulties in coverage and quality [1].

Additionally, considering that the distribution of professionals in the majority of the developing countries is concentrated in big urban zones, it is decreased the possibilities of the specialized medical attention in rural zones, little towns and little cities even capitals with medium population [2].

Equally exists a population highly vulnerable in function of the isolation of its regions of the development centers, due then this are low socioeconomic population than has Access to a hospital infrastructure with limited specialized health services and an inadequate road structure. This is the reality that lives departments like Chocó, Amazonas, Vaupés, and Guainía. Of this way the government cannot ensure adequately the fundamental rights of the health in all the national territory, being feasible according to telehealth the coverage amplitude [3].

From this point of view, and dealing of solving coverage health problems than Colombia presents it has been begun to implement solutions of telehealth [4], which defines strategies that allows improving the amplitude of the health coverage according to the use of informatics, electronic and telecommunication tools. This synergy between communications and health technology allows an increase of the early diagnostics and effective sick treatments [4]. This allows to the remote communities with a low socioeconomic level of the national territory to Access the specialized medical services without to displace to principal cities [5].

This strategy has been used successfully in some African countries [6] [7] and in general in countries of developing countries. For example, in Brazil exists the primary attention program that favors to 11 states which are attended according telemedicine close to 1100 municipalities [8].

The develop propose is focused on the development and the advance in telemedicine with the objective to expand coverage, which would allow a strengthening of health infrastructure. The idea is to support the health centers to the isolated regions of the country, through health center located in urban zones, which has high capable personal. This will achieve making an architecture that allows the web interaction between a patient and a specialized medical doctor than is geographically distant.

Inside the telemedicine, this paper will pay special attention to the physiotherapeutic area. Thus is defining a serviceoriented architecture with the objective to achieve a dispersed geographical environment of patients and professionals of health highly capable in physical rehab. Considering the big consequences of an inadequate specification of the system, it is proposed a procedure of modeling based on a formal tool like it is the Petri Net, for the definition of the teleoperation system of the assistant dispositive like the integration and coordination of itself. For this is considerate the idea of dynamic system oriented (DSO). Finally with the objective of an assessment in the project proposal is considerate the implementation of an 
example of a practical application that in this case will be a passive movement rehab machine for knee articulation.

\section{Theoretical FrameworK}

\section{A. Service oriented architecture (SOA)}

An architecture SOA (Service Oriented Architecture) establish a design framework of the integration of the independent architecture of a way that since the web can Access to its functions which it is offered like services. The most habitual way to implement is according to web services [9].

It does not exist a standard definition of SOA, by the way, the only can proportionate is a set of principles that are very associated with the services orientation. According to [10], some of these principles which rule the behavior of a determined Service and its interaction with others are reusability interoperability auto-content, under assembly without the state, scalability, modularity easy to discover between others.

Since this point of view, the strategy of services orientation allows the creation of services and applications composes than can exist with Independence of the underlying technology. Instead to demand than all the data and the logic is on the same computer the orientation modeling services facilitates the Access and the consumption of resources by the net [9].

\section{B. Petri Net}

Petri Net were created by Carl Adam Petri in 1962. Next is presented the principal components of a Petri Net [11]:

- Places (p): represented graphically according circumferences

- $\mathrm{P}=\{\mathrm{p} 1, \mathrm{p} 2, \mathrm{p} 3, \ldots, \mathrm{pn}\}$, is a finite set of places, $\mathrm{n} \geq 0$.

- Transitions (t): represents by vertical or horizontals straight segments. $\mathrm{T}=\{\mathrm{t} 1, \mathrm{t} 2, \ldots, \mathrm{tm}\}$, is a finite set of transitions, $\mathrm{m} \geq 0$.
- Directed arc (arrows): define the income and output of a transition to a place or from a place to a transition Marks ("token"): a mark is represented according a point in the interior of a place. The places contains any number of marks; the transitions consume marks since an input and generate marks of arrival places.

In a general way, the places and transitions have the next characteristics:

- Each place has associated a system state.

- To the transitions are associated events that happen a state change

A transition is enabled if each inlet has as minimum one quantity of marks equally to the arc weight than has associated, past is shown outlined next:

\section{BACKGROUND}

\section{A. Telemedicine in Colombia}

In Colombia, the telemedicine has been developed in different ways. For example, in [12] is presented the telemedicine problem applied to the psychiatric consults, which is a job developed by the Universidad CES of Medellin. Authors propose a structuration protocol of teleconsult for patients with problems associated to psychiatric. For this, it was developed a web application that is able to provide diagnostics services and patient control through video conferences.

Another example of telemedicine is presented in [13]. In this work is designed and developed by an information system prototype of big utility for the general doctors serving support for the consult and the modification of clinics histories, remission to the specialist and to make the clinical recipe for each patient. This was a job developed by students of the Universidad Distrital of Bogotá.

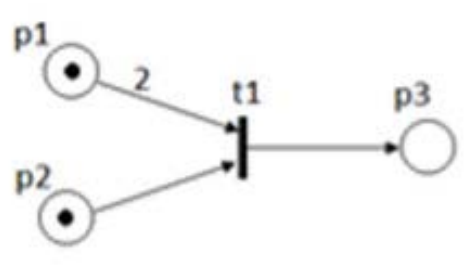

a) t1 Not enabled to fire

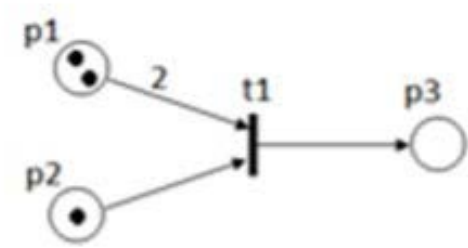

b) t1 enabled to fire

Fig. 1. Petri Net: Release Condition 
In [14] is presented a work made by investigative groups of the Universidad Pedagogica y Tecnologica of Colombia (Tunja) and the Universidad Antonio Nariño (Bogota). This work is made in the telefisiotherapist campus and it has like objective attend people with motors disease in the superior members. The architecture presented in this investigation makes the monitoring of the biomechanical movement of a patient. In this way, a specialist doctor can obtain information about the movement of a person and give its concept about the advance and in which stage of recovering is found the patient.

\section{B. Telemedicine in the world}

The telemedicine has come developed some years ago and acquiring a big importance in countries where the health coverage is insufficient for the population. An example of this is the part of Africa called "Black Africa" or "SubSaharan Africa" where the big part of the hospitals is found in urban zones and the populations of rural zones (composing the $70 \%$ of the population) are obligated to displace long distances to receive medical treatments [15]. In Ethiopia (for example), the telemedicine has brought help through the web in tele-oftalmology, tele-consults and teleeducation services [15].

In [16] authors propose the implementation of a system of telemedicine to improve the medical attention in patients with cardiorespiratory difficulties. The fundamental advantages of this proposed system are rise of the efficiency through the optimization of the assistant resources and decrease of the displacements of the patient to the health center. For this end, it is put like a bracelet to the patient which will be of big utility to make the monitoring 24 hours by day, 7 days to the week.

Another example of the telemedicine, and more specifically in physiotherapy, is the study made in [17] which presents an innovated platform of telephysiotherapy, implemented through the internet, which brings support to the traditional one than normally is based on sessions that the patient must accomplish in hospitals. The developed platform proposes a tridimensional visual exit to feedback the patient to motivate and show the advance of the therapy.

In [18] is presented the design of a prototype of an integrated mobile telemedicine. This system has two parts: One part where is making the signal measurement, and the other part where is making the process signal. It is used a net to transmit audio and video of the vital signs of a person in an ambulance in movement to be delivered to the doctor personal computer. The Vital signs than are monitoring are the arterial pressure, the oxygen saturation in blood, body temperature, concentration of glucose in blood, heartbeat frequency and others. This is a prototype making with the purpose of support the emergency area in a hospital with the goal to save time that could be vital for the patient wealth.

In [19] is presented a development of an information monitoring system in telemedicine. This system receives of first-hand vital signs by wireless. The vital signs than are measured in this case are blood pressure glucose levels, body temperature, and others. These measurements are sent online in a health center through a platform of health services. This service integrated to telemedicine is based on the concept of SOA using the web-services technology to make easy the integration between heterogeneous systems.

\section{Proposed Architecture}

In Fig. 2 is presented the general architecture, which plans the design through a system modeling based on a formal tool like the Petri Nets. This has the purpose of assuring that the telemedicine process be taken successfully.

On Fig. 2 is necessary to make some clarifications. On the first hand, you must recognize the System "Actors" (People who intervene in the therapy), which it describes next.

Specialist Doctor: Is located in a high technology hospital and it will be in charge to make the correspondent therapy according to the clinic history of the patient.

Patient: He/She will be the person that is in the isolated hospital receiving the supply therapy for the specialist.

Coequiper: Is of big importance, because is a support person in the therapy process. This coequiper must be in the isolated hospital to help the patient in the dispositive connection job, just like inform the doctor the therapy process.

From this point of view, and treating to develop an architecture oriented to services for the passive machine movement teleoperation problem for physical rehab, it has been defined the next services:

Teleoperation System: Here is where it is generated the telecommands for the control of the machine and it generates all the necessary process to take the therapy. This service will be activated or consumed by the specialist. 
Isolated Hospital Services: This Service will be in charged to receive the telecommands, send to the machine and feedback the teleoperation services about the executed therapy state.

Physical Rehab Machine Service: It is in charge of the execution of the therapy and the interaction with the patient. Here is found the sensors, system actuators, and the machine or dispositive of medical assistance.

\section{Dynamic of the Proposal Architecture}

Next, it is shown the general net of this architecture. It is important to notice that the defined services, the communication observer and the database are represented inside the transitions-frame making the use of hierarchies, which is a clear advantage of the Color Petri Net in front of the ordinary ones.

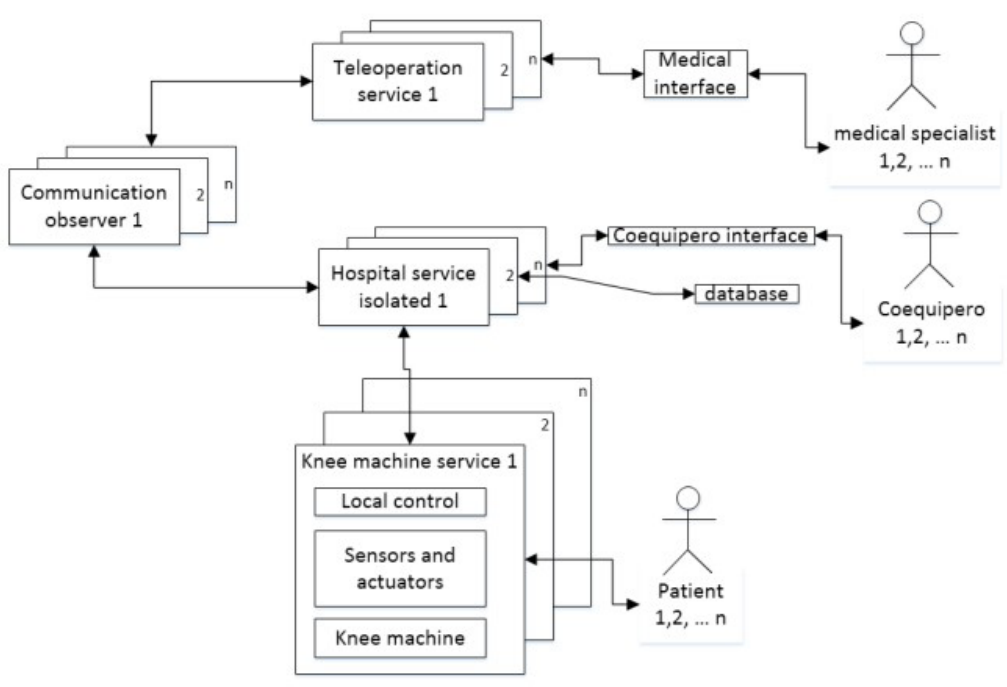

Fig. 2. Proposed Architecture.

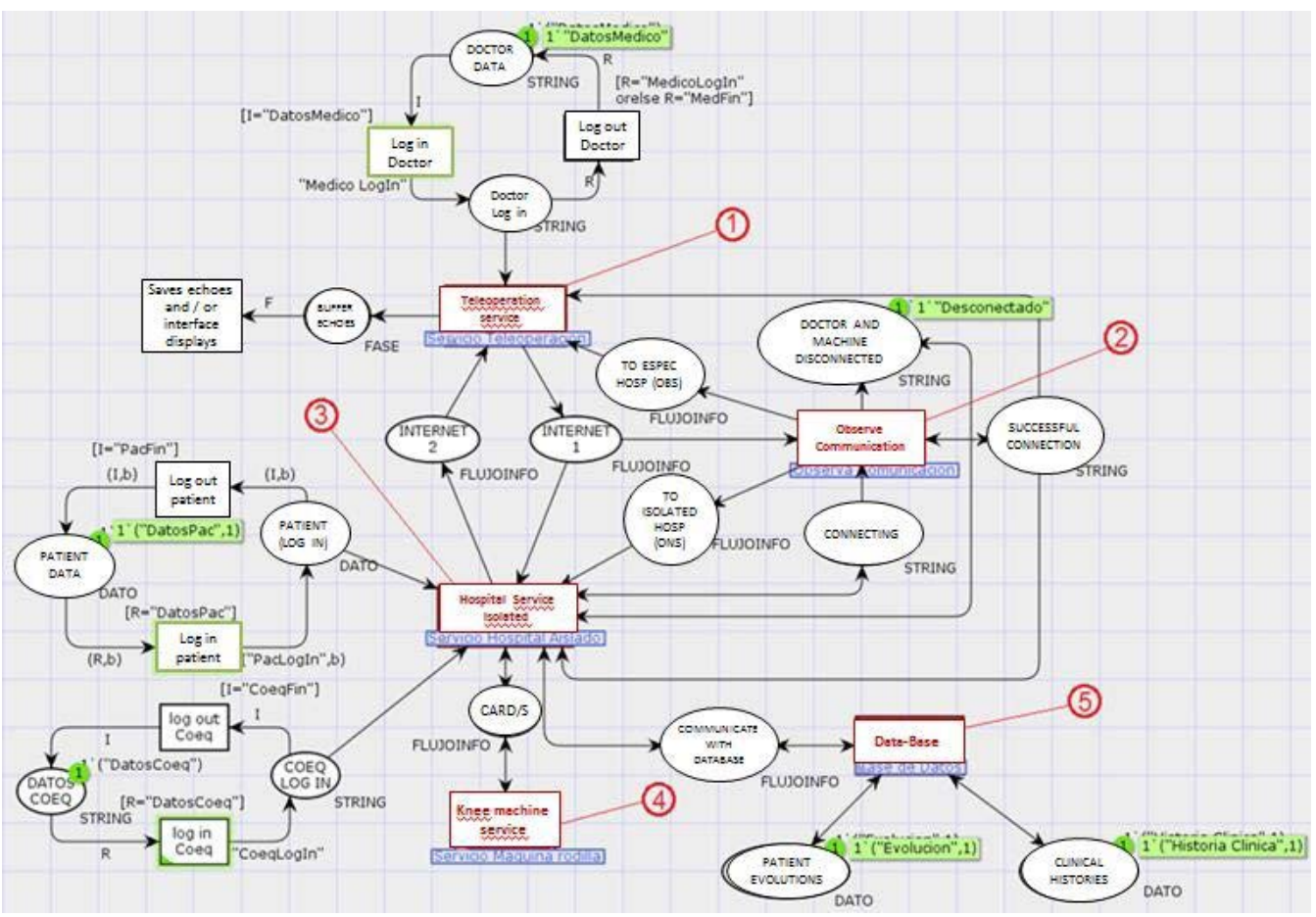

Fig. 3. General Net 
An important aspect of marking in the Fig. 3 is that the services which are communicated through online are the services named Teleoperation Service and Isolated Hospital Service (Numeral 1 and 3 on Fig. 3 respectively).

To communicate with them, it is used two places called "Internet 1" and "Internet 2". These places work like inlet and output of information. It is clear that generally this places only represent a communication channel (In this case Internet).

Also, it is easy to notice that it could have used an only place called "online web" which it would accomplish easily the inlet and outlet information. It is decided to use two places because it makes easy the model organization and simplifies its understanding.

Of this way, the place "Internet 1" is the output for the Teleoperation Services but it is from the inlet for the Isolated Hospital service. The opposite occur with the place "Internet 2" (Watch Fig. 3).

One of the challenges of this work was assembly the three services that compose the architecture. For this, it was used some hierarchies, that allows the modeling in each one of the services separate, for then establish the way in this goes to communicate between them.

This is how it was used of many transitions or operations that execute a process to the interior or exterior service. Next, it is shown a summary of the transitions (or operations) that each service makes during the physiotherapy.

The used conventions in the Fig. 4 are shown next:

- $(+)$ When the transition is communicated with other Service

- (-) When the transition is communicated in the

Service interior

- $\left({ }^{*}\right)$ When the transition is communicated with the data base.

Fig. 4 presents a big importance now because its nature is similar to a class diagram. This makes easy the programming and the implementation of the developed model.

\section{Conclusion}

In general, the background is lack of a specific way of modeling. Additionally, it presents a different focus oriented to the services which limit the system scalability and the possibility of interaction patient-professional of the health independently of the geographic localization. From there the importance to search about dispersed system modeling, now that it wants to develop a synchronous system which will be designed and analyzed with the use of a modeling formal tool (Petri net) making sure the orientation of the services to the proposal architecture.

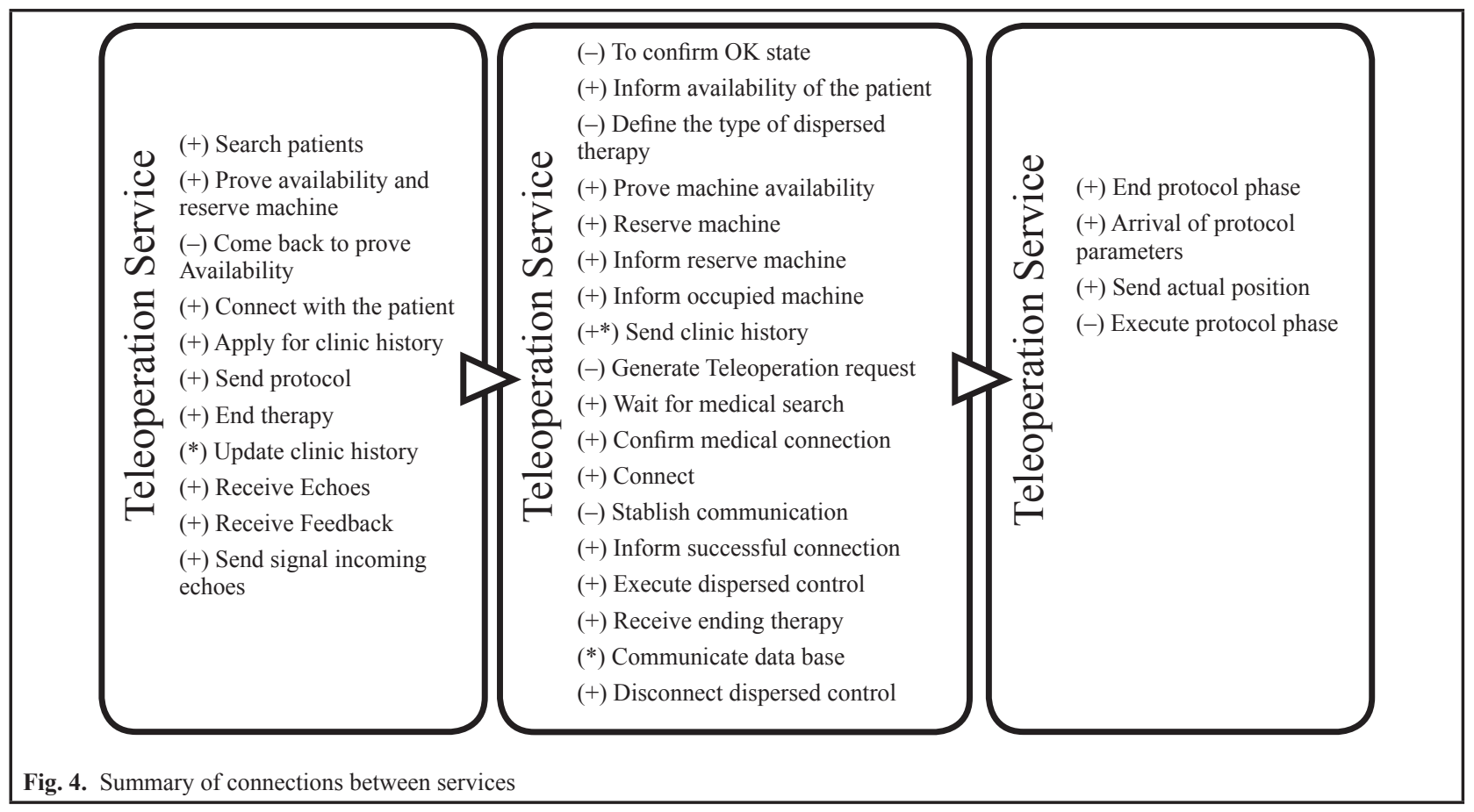


In general, what this paper propose an architecture that allows the teleoperation of medical devices focused on physical rehabilitation through the synchronous teleoperation of passive movement machines which are useful for treating patients with disabilities. Using petri nets allowed to visualize the evolution of the states of the architecture and to diagnose possible improvements in similar systems.

\section{REFERENCES}

[1]. E. Rodríguez, "Telesalud en Colombia," Ministerio de la proteccion social, 2012. [Online]. Available: http://www. acreditacionensalud.org.co/catalogo/docs $\quad /$ Revista\%20 Normas\%20y\%20 Calidad\%20N\%C2\%B0\%2090.pdf. [Accessed 15 febrero 2013].

[2]. A. Lozano and E. Romero, "Telemedicina y telerradiología. La experiencia en la Universidad Nacional," Revista Colombiana de Radiologia, pp. 2435 - 2439, 2008.

[3]. M. Ortúzar, "Igualdad de acceso a la telesanidad en zonas rurales y aisladas: propuesta de un marco ético normativo integral de acceso y distribución," Revista Latinoamericana de Bioética, pp. 76-93, vol 9., 2009.

[4]. A. Kopec and G. Rodriguez, "Aplicaciones de telecomunicaciones en salud en la subregion Andina," Organismo Andino de Salud-Convenio Hipolito Unanue, Bogota DC, 2006.

[5]. Telesalud Universidad de Caldas, "Centro de Inovacion en e.salud," Telesalud Caldas, 2010. [Online]. Available: http:// telesalud.ucaldas.edu.co/telesalud/. [Accessed 20 febrero 2013].

[6]. G. Observatory for eHealth, Telemedicine Opportunities and Developments in Member States, Switzerland: World Health Organization, 2010.

[7]. RUTE, "Em benefício da integração da comunidade de telemedicina," Rede Universitária de Telmedicina, 2013. [Online]. Available: http://rute.rnp.br/. [Accessed 16 Septiembre 2013].

[8]. Governo Federal Brasil, "Telessaúde Brasil Redes," Ministerio de Saúde, 2013. [Online]. Available: http://www.telessaudebrasil.org. br/. [Accessed 16 Septiembre 2013].

[9]. Microsoft Corporation, La arquitectura orientada a servicios (SOA) de Microsoft aplicada al mundo real, Estados Unidos, 2006.

[10]. M. Josuttis, SOA in Practice the Art of Distributed System Design, United States: O'Reilly, 2007.

[11]. R. Zurawski and M. Zhou, "Petri nets and industrial aplication: A tutorial Industrial Electronics," IEEE Transactions, vol. 41, no. 6, pp. 567-538, 1994.

[12]. N. Londoño, P. Castaño, D. Montoya and C. Ruiz, "Protocolo de telemedicina para la consulta psiquiátrica," Revista Ingeniería Biomédica, vol. 3, no. 5, pp. 43-49, 2009.

[13]. D. Roncancio, J. Beltran, W. Cardenas, C. Montenegro and P. Gaona, "Prototipo de Telemedicina Móvil para Asistencia Médica Domiciliaria y Remota," Eighth LACCEI Latin American and Caribbean Conference for Engieneering and Technology, 2010.

[14]. M. Callejas, A. Ruiz and R. Gutiérrez, "Métodos de Captura de Movimiento Biomecánico Enfocados en Telefisioterapia," in Intercambios de cuidado médico panamericanos, Medellin (Colombia), 2013.
[15]. M. Kifle, V. Mbarika and P. Datta, "Telemedicine in sub-Saharan Africa: The case of teleophthalmology and eye care in Ethiopia," Journal of the American Society for Information Science and Technology, pp. 1383-1393, Vol 57, 2006.

[16]. R. Alvez, "Aplicación de Telemedicina para la mejora de los sistemas de emergencias y diagnósticos clínicos," Memoria de trabajos de difusión científica y técnica, vol. 9, pp. 91-97, 2011.

[17]. V. Siang, S. Zhuo, A. Phyo, M. Jayachandran, J. Biswas, L. Siew Yee and P. Yap, "Innovative Platform for TelePhysiotherapy," in 10th International Conference on e-health Networking and Services, Singapore, 2008.

[18]. D. Jung, K. Kim, G. Kim, D. Shim, M. Kim, B. Choi and D. Suh, "Biosignal Monitoring System for Mobile Telemedicine," in Enterprise networking and Computing in Healthcare Industry, 2005. HEALTHCOM 2005. Proceedings of 7th International Workshop, 2005.

[19]. K. Kifayat, P. Fergus, S. Cooper and M. Merabti, "Body Area Networks for Movement Analysis in Physiotherapy Treatments," in IEEE 24th International Conference on Advanced Information Networking and Applications Workshops, Liverpool, 2010. 